This PDF is a selection from an out-of-print volume from the National Bureau of Economic Research

Volume Title: New Developments in Productivity Analysis

Volume Author/Editor: Charles R. Hulten, Edwin R. Dean and Michael J. Harper, editors

Volume Publisher: University of Chicago Press

Volume ISBN: 0-226-36062-8

Volume URL: http://www.nber.org/books/hult01-1

Publication Date: January 2001

Chapter Title: The BLS Productivity Measurement Program

Chapter Author: Edwin Dean, Michael Harper

Chapter URL: http://www.nber.org/chapters/c10123

Chapter pages in book: (p. 55 - 84) 


\title{
The BLS Productivity Measurement Program
}

\author{
Edwin R. Dean and Michael J. Harper
}

\subsection{Introduction}

Productivity measurement has long been an important activity of the U.S. Bureau of Labor Statistics (BLS). This program has evolved over the years, stimulated by changes in data availability, by new developments in the economics literature, and by the needs of data users. The program's first major activity was the publication of industry measures. Following the development of the National Income and Product Accounts (NIPA) at the U.S. Department of Commerce, the BLS introduced productivity measures for the aggregate U.S. economy. More recently, BLS has developed measures of multifactor productivity (MFP).

This paper discusses the current status of the BLS program, with emphasis on the data development work done in recent years. By way of background, we first review the status of the BLS program as of the mid1970s (section 2.2) as well as some important advances in the economics literature that had occurred by that time (section 2.3). The paper then describes the development of MFP measures for the private business and private nonfarm business sectors - these were first published in 1983 - as well as recent work to expand and improve these measures (section 2.4). It also describes recent extensions and improvements to measures for the manufacturing sector and for more detailed industries both within and

Edwin R. Dean is former associate commissioner for productivity and technology, Bureau of Labor Statistics, U.S. Department of Labor. He is currently adjunct professor of economics at The George Washington University, Washington, D.C.

Michael J. Harper is chief of the division of productivity research of the Bureau of Labor Statistics. 
outside manufacturing (section 2.5). Finally, it provides comments on the potential for further improvements in the measures (section 2.6).

\subsection{Background on the Industry and Aggregate Labor Productivity and Cost Measures}

\subsubsection{The Early BLS Productivity Program}

The BLS was calculating productivity data for some industries by the 1920s. These measures compared the number of goods produced to the number of people needed to produce them. The immediate consequence of a productivity improvement can be the displacement of workers. The problem of displacement was the stimulus for the BLS productivity measurement program. According to Goldberg and Moye (1984, 168), "In 1935 , the Bureau applied to the WPA for funds to conduct studies of productivity in 50 industries." In 1941, after initial studies were published, Congress appropriated funds for a program of continuing studies of productivity and technology. The BLS focused initially on measures of productivity and unit labor costs for manufacturing industries. The concern about worker displacement affected the methodology selected. It was believed that the preferred weights for aggregating outputs for the computation of an ideal productivity index were labor requirements. Essentially, productivity gains were weighted by the associated job losses.

In addition to publishing measures of productivity, the BLS productivity and technology program prepared qualitative information on technological developments in various industries. According to Goldberg and Moye $(1984,169)$, these were "for the use of U.S. agencies and those of allied governments." These qualitative reviews were abandoned in 1994 due to budget cuts.

\subsubsection{The Development of Aggregate Measures of Labor Productivity and Costs}

The Great Depression and World War II each played a role in shaping the NIPAs upon which BLS (1959) would base its aggregate productivity measures. Keynes' description of aggregate demand and Leontief's inputoutput models became central elements in the NIPAs. As Berndt and Triplett (1990) reminded us, the Conference on Research in Income and Wealth (CRIW) was also an influential part of this process. Using the Accounts, BLS (1959) introduced annual indexes of real product per manhour for the total private economy and for the private nonagricultural economy. (Measures for total manufacturing had been introduced in 1955.) The aggregate measures were developed under the supervision of Jerome A. Mark. Before long, the Bureau was publishing these measures quarterly. 
The BLS aggregate output per hour series involved the matching of employment and hours collected in BLS surveys to output measures for selected NIPA sectors. Any difference in coverage can introduce a bias into the productivity trend. In limiting the measures to the total private sector, BLS $(1959,1)$ recognized that "there is no satisfactory method of measuring the goods and services provided by the government." In part, government output in the NIPAs was measured using data on labor inputs, which implies no productivity change.

Since 1976, BLS has published quarterly indexes of labor productivity, compensation per hour, and unit labor costs for the following sectors: business, nonfarm business, manufacturing (and its durable and nondurable goods-producing subsectors), and nonfinancial corporations. ${ }^{1}$ Table 2.1 presents trends in output per hour, unit labor costs, hourly compensation, and real hourly compensation.

The data in table 2.1 indicate that there was a slowdown in productivity after 1973 in all six sectors. Since 1979, output per hour trends have recovered in manufacturing, due mainly to exceptional strength in durable manufacturing. Since 1990, output per hour growth has recovered partially in business and nonfarm business - though rates have remained well below their pace in the pre-1973 period. For nonfinancial corporations, the post1990 recovery has been complete. Unit labor costs rose sharply after 1973, but since 1990 they have risen more slowly than in the pre-1973 years. Finally, real hourly compensation (compensation per hour deflated by the consumer price index [CPI]) has generally risen more slowly than output per hour, and the difference has been especially large since 1979.

\subsection{Advances in Production Theory and Their Implications for Productivity Measurement}

\subsubsection{Developments in the Economic Literature on Productivity}

By the mid-1970s, there was a significant accumulation of research relevant to productivity measurement that had not yet been reflected in government measures. The idea of using production functions as a means of analyzing aggregate economic activity was pioneered by Paul Samuelson (1947). The function, $f$, reflects the maximum amount of output that can be produced by various combinations of inputs of labor, $L$, and capital, $K$, given the technology available at time $t$ :

1. In addition to excluding general government, the business sector also excludes the following components of GDP: private households, nonprofit institutions, and the NIPA imputation of the rental value of owner occupied dwellings. Like government, households and institutions are excluded because they are measured with labor inputs. Owner occupied housing is excluded because no corresponding labor hours data are available. 


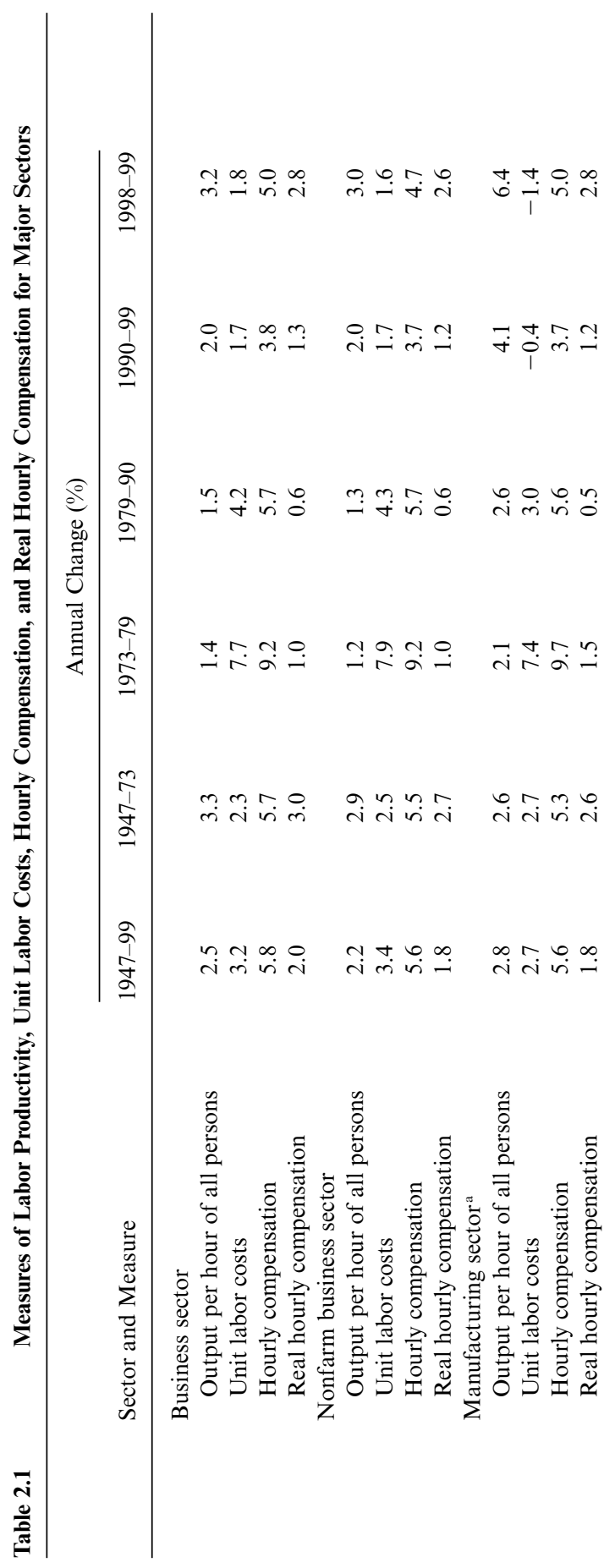




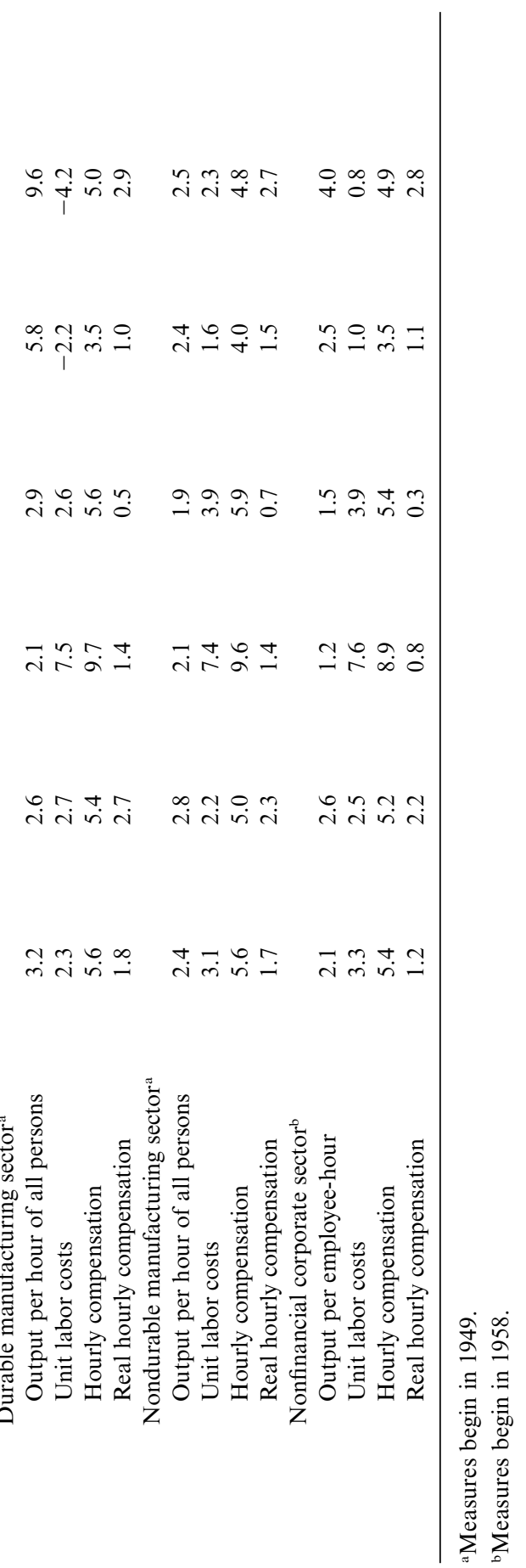




$$
Y=f(K, L, t) .
$$

Robert Solow (1957) used a production function to show the role of capital in labor productivity trends. By assuming a production function and perfect competition in input factor markets, we can calculate the rate at which the production function is shifting:

$$
\frac{d \ln f}{d t}=\frac{d \ln Y}{d t}-s_{L} \frac{d \ln L}{d t}-s_{K} \frac{d \ln K}{d t},
$$

where $s_{L}$ and $s_{K}$ are the shares of labor and capital, respectively, in total cost. We call the rate at which the function is shifting the growth rate of MFP; MFP is also referred to as total factor productivity, or the "Solow residual." Solow showed that the rate of growth of labor productivity depends on the growth rate in the capital-labor ratio (weighted by capital's share) and the growth rate of MFP:

$$
\frac{d \ln \left(\frac{Y}{L}\right)}{d t}=s_{K} \frac{d \ln \left(\frac{K}{L}\right)}{d t}+\frac{d \ln f}{d t} .
$$

Solow argued that MFP is a better measure of technological change than labor productivity, but he also acknowledged that MFP reflects many other influences, because it is calculated as a residual.

The usefulness of aggregate production models and of aggregate capital stock measures had been debated in the literature during the 1950s. At issue was the validity of assuming that microeconomic relationships applied to aggregate data, as well as the validity of aggregating capital. The literature of the 1960s reflected an effort to build aggregate measures from increasingly detailed data using less restrictive assumptions about aggregation. Evsey Domar (1961) demonstrated how a system of industry and aggregate production functions could be used to compare industry productivity measures to the aggregate measures. A paper by Dale Jorgenson and Zvi Griliches (1967) showed how detailed data could be used to construct a capital aggregate without making strong assumptions about the relative marginal products of dissimilar assets. Also, it was recognized that commonly used index number formulas could introduce bias into the aggregation process. Diewert (1976) showed how production functions could be used as a basis for determining which index number formulas were least restrictive.

In the literature on productivity measurement, the Tornqvist (1936) index is the changing-weight index that has been used most frequently. The Tornqvist index employs as weights an average of the cost shares for the two periods being compared. The index number, $X$, is computed in logarithmic form: 


$$
\ln X_{t}-\ln X_{t-1}=\sum_{i}\left[s_{i}\left(\ln x_{i t}-\ln x_{i t-1}\right)\right],
$$

where $x_{i}$ designates inputs, $n$ inputs $(1 \ldots i \ldots n)$ are being considered, the two time periods are $t$ and $t-1$, and the cost share weights, $s i$, are computed as

$$
s_{i}=\frac{1}{2}\left\{\left[\frac{c_{i t} x_{i t}}{\sum_{i}\left(c_{i t} x_{i t}\right)}\right]+\left[\frac{c_{i t-1} x_{i t-1}}{\sum_{i}\left(c_{i t-1} x_{i t-1}\right)}\right]\right\} .
$$

Here $c_{i}$ is the unit cost of the input. An index number time series is retrieved by "chaining" these logarithmic differences and by using the exponential function.

The literature on the theory of index numbers has shown that the Tornqvist index of inputs has several desirable properties. In particular, Diewert (1976) demonstrated that the Tornqvist index is consistent with the flexible translog production function.

\subsubsection{The panel to review productivity statistics}

By the mid-1970s it was recognized that productivity growth trends had slowed dramatically. A flurry of research studies aimed at explaining the slowdown. Much of the analysis relied on concepts that went beyond labor productivity. The researchers often had to compile their own data sets to address the specific issues that interested them.

The Committee on National Statistics of the National Academy of Sciences (NAS) appointed a Panel to Review Productivity Statistics. The panel, chaired by Albert Rees, wrote a report (NAS 1979) making twentythree recommendations to government statistical agencies; many of these recommendations were directed to the BLS productivity measurement program. Among these were that the BLS should develop a "survey of hours at the workplace" (recommendation 8), that BLS should study "the use of weighted labor input measures" (recommendation 9), and that the BLS should "experiment with combining labor and other inputs into alternative measures of multi-factor productivity" (recommendation 15). The report made specific mention of capital, weighted labor, and intermediate purchased inputs for inclusion in the MFP work. Many of the other recommendations were aimed at improving the scope and accuracy of productivity statistics by expanding source data on outputs, prices, and labor.

\subsection{The Development of Major Sector Multifactor Productivity Measures}

Following the NAS recommendations, BLS launched an intensive effort to develop additional input measures suitable for publication with its pro- 
ductivity measures. This effort was facilitated by additional funding for MFP measurement, provided by Congress beginning in 1982 .

\subsubsection{The Development of Aggregate Measures of Capital Service Inputs}

The first project was to construct capital measures that would be comparable to the output per hour measures for aggregate sectors. Among the issues faced by BLS were what to include in capital and how best to aggregate detailed data on investment by vintage and by asset type.

A review of "the domain of definition of capital" issue in the context of productivity measurement was provided to the CRIW by Diewert (1980). After reviewing precedents, including Christensen and Jorgenson (1969), Denison (1974), and Kendrick (1976), Diewert recommended that capital measures include "structures, land, natural resources, machinery and other durable equipment, and inventory stocks used in the private business sector" (1980, 480-85). Diewert emphasized that the omission of either land or inventories would bias estimates of the contribution of capital to productivity. Financial assets and other intangible assets were excluded, mainly due to unresolved measurement issues.

An important result of production theory is that it is desirable to aggregate capital goods in terms of their marginal products in current production as distinct from the marginal costs of producing the capital goods. This leads to two fundamental steps that have been adopted in the BLS capital work: aggregation of vintages based on "relative efficiency," and aggregation of different types of assets using "rental prices."

The perpetual inventory method (PIM) is used to aggregate a time series of real investment. ${ }^{2}$ The PIM involves an assumption about the deterioration of investment goods as they age. ${ }^{3}$

Hall (1968) showed that the rental price is the relevant margin on which to aggregate capital goods of different types. The rental price, $c$, reflects the price of new capital goods, $p$, the nominal discount rate, $r$, the rate of economic depreciation, $\delta$, and the rate at which goods prices appreciate, $\Delta p$ :

$$
c=p r+p \delta-\Delta p .
$$

Jorgenson and Griliches (1967) used implicit rental price estimates to aggregate the services of assets of different types. Another innovation in aggregation procedures attributable to Jorgenson and Griliches was the use of chained Tornqvist indexes to aggregate capital assets of different types. The growth rate of total capital input, $\Delta \ln K_{T}$, between successive

2. Real investment is created by dividing a nominal investment series by a price index, $p_{a, t}$.

3 . The process of deterioration is usually modeled with an age-efficiency schedule. The capital stock is then the sum of weighted past real investments, the weights coming from this schedule. 
periods ( $t-1$ and $t$ ), was computed as a weighted sum over asset types, $a$, of the growth rates of asset stocks, $\Delta \ln k_{a}$. The weights were the arithmetic means of the shares, in the two periods, of the implicit "rents" generated by the respective assets in total rents. This procedure led to the following:

$$
\Delta \ln K_{T}=\Sigma_{a} \Delta d \ln k_{a}\left\{\frac{1}{2}\left[\left(\frac{k_{a, t} c_{a, t}}{\sum_{i} k_{i, t} c_{i, t}}\right)+\left(\frac{k_{a, t-1} c_{a, t-1}}{\sum_{i} k_{i, t-1} c_{i, t-1}}\right)\right]\right\} .
$$

Most of the data needed to estimate rental prices are readily available. Jorgenson and Griliches estimated the discount rate as an "internal rate of return." This involved assuming that implicit rents in each time period account for the total of "property income," $\Psi_{t}$, in each period. Property income was assumed to be the residual derived by subtracting labor costs from nominal value added in the sector under study. Thus they solved for a single, $r_{t}$, for each sector, such that

$$
\Psi_{t}=\Sigma_{a} k_{a, t} c_{a, t}=\Sigma_{a} k_{a, t}\left[p_{a, t} r_{t}+p_{a, t} \delta_{a}-\left(p_{a, t}-p_{a, t-1}\right)\right] .
$$

Empirically, the main effect of using these techniques is to place relatively larger weights on assets that are depreciating quickly, compared to the weights that would result from a direct aggregation of stocks. The rationale for placing more weight on short-lived assets is the following: Investors must collect more rents on a dollar's worth of short-lived assets to compensate for their higher depreciation costs. Hall and Jorgenson (1967) formulated the rental prices to reflect the effects of tax laws. In the United States, tax laws have tended to favor shorter-lived assets, and account should be taken of this effect in a model that implicitly allocates property income to asset rents.

These and related advances in the literature strongly influenced the BLS approach to capital measurement. The BLS uses Tornqvist aggregation, formulating rental prices with Hall-Jorgenson type tax parameters and a Jorgenson-Griliches type internal rate of return, computed using property income data from the NIPA.

The BLS built its capital measures on earlier work by the Bureau of Economic Analysis (BEA). The BEA had begun measuring capital stocks in the 1960s in an effort to improve the NIPA estimates of capital consumption allowances (CCA). BEA used capital stocks, which were based on historical investment data, to adjust its CCA estimates, which were based on tabulations of business tax returns. The capital stock approach to CCA estimation was deemed preferable because, unlike the tax returns, it used consistent accounting conventions. The BEA capital stock work was reported to the CRIW by Young and Musgrave (1980).

As BLS developed its capital measures, a series of papers were prepared 
for discussion with other productivity researchers. The first set of capital measures completed was presented by Norsworthy and Harper (1981; henceforth NH). ${ }^{4}$ Their approach to coverage, detail, and methods of aggregation was fairly similar to the study by Christensen and Jorgenson (1970).

The NH study went on to address the issue of aggregation of stocks of assets of different types. In this area, the study closely followed the procedures of Jorgenson and Griliches (1967) described earlier. Implicit rental prices were estimated for each of five asset types, and these were used to construct chained Tornqvist indexes of capital inputs. The resulting capital input measures grew about 0.2 percent per year faster than comparable "directly aggregated" capital stocks.

The same capital measures were used in a broader study of factors affecting productivity by Norsworthy, Harper and Kunze (1979; henceforth NHK). This paper contained a discussion of the issue of vintage aggregation. The available options were to use either the BEA gross or net stocks of capital. The BEA gross stocks assumed there were discards, but no depreciation; the BEA net stocks assumed there was straight line depreciation. Denison (1974) had used a 3:1 weighted average of gross and net stocks in his growth accounting work. ${ }^{5}$

NHK extended the scope of the MFP analysis beyond capital to look at other quantifiable influences on productivity. These included the effects of changing labor composition (to be discussed shortly), the effects of expenditures on pollution abatement equipment, and the effects of cyclical factors. NHK presented the MFP measures in terms of an equation similar to the one used by Solow (1957). This equation, which was derived from a production function, helps explain the differences between labor productivity and MFP. If $y, l, k$, and $a$ are the growth rates of output, labor, capital, and MFP respectively, then

$$
(y-l)=a+s_{k}(k-l)
$$

4. This work was first reported in a January 1979 BLS working paper. The NH study worked with BEA net capital stock measures for three major subsectors of the private business sector: manufacturing, farm, and nonfarm-nonmanufacturing. For each sector, $\mathrm{NH}$ obtained BEA stocks of nonresidential structures and equipment and of residential capital owned and rented by private businesses. (Rented residential capital was included to ensure that the domain of the capital measures matched the data on labor hours and outputs used in the study.) The NH study also made estimates of inventories and land. The five asset categories included in the estimates (structures, equipment, rented residential capital, inventories, and land) were fairly close to the domain of capital measures recommended by Diewert for productivity work. The present BLS measures still cover this same domain.

5. The NH and NHK studies elected to use the BEA net stocks, although it was noted that "there is evidence that the net capital stock understates and the gross stock overstates real capital input" (NHK, 399). 
where $s_{k}$ is the share of capital income in the nominal value of output. Thus, labor productivity grows because of "shifts in the production function," $a$, and also because of increases in capital intensity. The NHK paper presented tables that illustrated this equation. BLS (2000) has continued to present its long-term MFP trends using tables like these (to be discussed later in this section, table 2.4).

\subsubsection{The First Measures of Capital Formally Published by BLS: \\ New Asset-Type Detail and New Assumptions about Vintage Aggregation}

Soon after the MFP work was funded, BLS 1983 issued a formal publication presenting new BLS data series on MFP. This publication presented series on output per unit of combined labor and capital inputs for private business, private nonfarm business, and manufacturing. This work was summarized by Jerome Mark and William Waldorf (1983), who directed the project. Although similar in coverage and technique to the NHK study, this first formal publication of MFP numbers reflected more-detailed data work than had been done for the earlier research.

Rather than simply use the BEA net stocks of equipment and structures, BLS (1983) applied the rental price and Tornqvist aggregation techniques to more detailed categories of asset types. ${ }^{6}$ In its estimation of capital consumption allowances, BEA had recognized that it is important to take account of changes in the mix of assets, because there is wide variation in the useful lives of assets. BLS recognized that the rental prices implied by different service lives would be quite different, and so the use of rental prices in aggregation from this amount of detail had the potential to reveal an important new dimension of capital composition change. It did indeed, as the new capital services input measure grew 0.8 percent per year faster than a corresponding directly aggregated capital stock! The comparable figure in the NH study, when only the five broad classes were used, was 0.2 percent. Thus, by applying the rental price and Tornqvist index techniques to the greater asset detail, changing capital composition contributed four times as much as it had when only the five broad asset classes had been considered.

The published BLS (1983) work, unlike earlier work by BLS researchers, did not make use of the BEA net stocks. With the cooperation of BEA, BLS obtained the asset-type detail underlying the BEA investment totals. Rather than use net stocks, BLS ran its own PIM calculations of stocks for detailed asset types. Harper (1983) had examined the issue of what to

6. BEA derived its net stock of equipment by adding together stock estimates for about twenty detailed types of assets. Similarly, BEA made separate stock estimates for fourteen types of nonresidential structures and ten categories of residential assets, each with its own service life. 
assume about the way that weights for investments decline as assets age. As mentioned earlier, it was clear from the literature that the appropriate weights for vintage aggregation would reflect the relative marginal products of the capital goods.

This posed a dilemma because, although there was some evidence on economic depreciation of sales prices, the BLS researchers could find only limited empirical evidence on the deterioration of capital services as a function of age. The mileage that trucks were driven declined only gradually during the first few years of their service lives, and then more rapidly later. ${ }^{7}$ BLS also consulted with people on its business and labor research advisory committees for their insights into patterns of deterioration. BLS adopted "age-efficiency" functions which declined gradually during the first few years of an asset's life and then more rapidly as the asset aged. BLS used a "hyperbolic" formula to represent the services, $s_{\tau}$, of a $\tau$-year-old asset:

$$
\begin{array}{ll}
S_{\tau}=\frac{L-\tau}{L-\beta \tau} & \text { for } \tau<L, \\
S_{\tau}=0 & \text { for } \tau<L,
\end{array}
$$

where $L$ is the asset's service life and $\beta$ is a shape parameter. For $\beta=1$, this formula yields a gross stock. For $\beta=0$, it yields a straight-line deterioration pattern. For $0<\beta<1$, the function declines slowly at first, and then more quickly later. BLS assumed $\beta=0.5$ for equipment and $\beta=0.75$ for structures. The formula was implemented assuming BEA's service-life estimates and assuming a discard process similar to the one used by BEA. ${ }^{8}$

\subsubsection{Reformulation of Capital Measures at the Two-Digit Industry Level}

Since their introduction, BLS capital measures have undergone several improvements, including reformulation at about the two-digit industry level. BEA completed a major data development project, reported by Gorman et al. (1985), to make investment data available for two-digit NIPA industries. ${ }^{9}$ BLS began work to apply the rental price and Tornqvist aggregation techniques to detailed asset-type data at the two-digit industry level. In this work, the nominal rate of return, $r$, was computed as a single

7. In addition, Ball and Harper (1990) studied cows as a capital asset in conjunction with measures of MFP being developed by the U.S. Department of Agriculture. They found that the output of a cow actually increases between the first and second years of her "service life."

8. With these assumptions, the BLS stocks were bounded by BEA's gross and net stocks. The BLS approach is effectively quite similar to that of Denison (1974).

9. This study made use of capital flow tables, developed as part of the BEA input-output work, to allocate industry investment control totals to approximately the same asset-type detail that had been available earlier at the sectoral level. The control totals were based on the BEA plant and equipment survey and quinquennial economic censuses with adjustments for NIPA conventions. 


\begin{tabular}{rr}
\hline & Rental Price \\
\hline 1971 & 0.2997 \\
1972 & 0.3518 \\
1973 & 0.5535 \\
1974 & -0.4473 \\
1975 & 0.1898 \\
1976 & 0.3425 \\
1977 & 0.4006 \\
1978 & 0.6294 \\
1979 & 2.0676 \\
1980 & 1.2731 \\
1981 & 0.4075 \\
\hline
\end{tabular}

rate of return within each two-digit industry. This work made it possible to develop two-digit level measures of capital and MFP. After an initial set of calculations, it was discovered that rental prices for some asset types in some two-digit industries were quite volatile from one year to the next. The problems appeared to be linked to large variations in the revaluation terms, $\Delta p_{a}=p_{a, t}-p_{a, t-1}$, of the rental price equations. The problems were most serious from the middle 1970s to the early 1980s, a period when inflation rates accelerated. Some rental prices were even negative. As an example, rental prices were experimentally calculated by BLS in 1986 for metalworking machinery in miscellaneous manufacturing industries. These prices, based on the new data and the earlier methodology, are presented in table 2.2. The volatility of individual asset rental prices led to instability of the shares in the Tornqvist aggregation of capital assets within some industries. This, in turn, led to some erratic movements in the aggregate index of capital inputs for these industries.

A research project was initiated to determine why the model did not work properly under these circumstances. Harper, Berndt, and Wood (1989, 336; hereafter HBW) pointed out that the implicit rental-price formula is "based on the assumed correspondence between the purchase price of an asset and the discounted value of all future capital services derived from that asset." Because the discounted value is dependent on the future, it is a function of investors' expectations. Changing expectations could account for the observed variations in the revaluation terms, $p_{a, t}-p_{a, t-1}$. HBW noted that theory provides no guidance on how best to measure either expected revaluation, $\left(\Delta p_{a}\right)$, or the discount rate, $r$. HBW then described various alternative means that had been used in the literature to estimate the rates of return and revaluation.

Following the recommendations of HBW, BLS decided to use a threeyear moving average of prices, $\left(p_{a, t}-p_{a, t-3}\right) / 3$, to estimate expected revalu- 
ation. BLS also decided to continue to calculate internal rates of return, except for a few instances in which the problem of volatile rental prices remained. ${ }^{10}$

\subsubsection{Empirical Evidence on Deterioration and Depreciation}

While the BLS (1983) had adopted a hyperbolic formula to represent the capital decay process, it had used the service life estimates developed by BEA. However, there was very little evidence in the literature on service lives, rates of decay, or economic depreciation rates. There was some evidence on the economic depreciation of structures developed by Hulten and Wykoff (1981), but relatively little on equipment. BLS began an effort to find additional evidence. As part of that effort, Berndt and Wood (1984) examined data on automobile depreciation, and Hulten, Robertson, and Wykoff (1989) examined machine tools prices.

Evidence has continued to accumulate. ${ }^{11}$ At a CRIW workshop on capital stock measurement, Triplett (1992) recommended that U.S. government agencies use the evidence already available while putting a priority on gathering additional evidence. BEA developed a plan for revising its service life estimates and depreciation measures. The available evidence was evaluated by Barbara Fraumeni (1997) and used by Arnold Katz and Shelby Herman (1997) to recalculate the BEA capital stocks. Rather than assume straight-line depreciation, BEA now assumes geometric depreciation of most asset types in computing its net stocks.

Detailed data associated with this new BEA work became available by September 1997. Using these data, BLS (1998) reestimated the two-digit capital input measures by type of asset. Because the productivity measures require a model of the deterioration of efficiency with age rather than one of economic depreciation, BLS continues to use its hyperbolic ageefficiency formula. However, BLS did adopt new service lives, based on the new information on depreciation published by BEA.

\subsubsection{Changes in the Composition of the Labor Force and Its Effects on Productivity}

The labor input data used in many studies of productivity are direct aggregates of hours worked or hours paid. However, worker skills are heterogenous and so some hours contribute more to economic production than do others. Hence, changes in the composition of the labor force can

10. In these cases, property income estimates in the NIPA were so low in some years that rates of return were negative. For these cases, BLS decided to assume a 3.5 percent rate of return on all assets, while deducting nothing for expected revaluation. The result is that BLS effectively assumes a 3.5 percent "real" rate of return for industries for which the three-year moving average fails.

11. For example, Ellen Dulberger (1989) and Stephen Oliner (1993) have studied depreciation of computers and their components. 
account for part of output growth. For many years, Dale Jorgenson and his colleagues, and (using a different approach) Edward Denison, prepared estimates of the impact on output of changes in the composition of the labor force. ${ }^{12}$ After considerable study, BLS researchers developed their own approach to this problem, culminating in a bulletin, Labor Composition and U.S. Productivity Growth, 1948-90 (BLS 1993). This introduced a methodology for measuring labor composition change. Since 1993, the BLS major sector MFP data have been measured net of the effects of changes in labor force composition.

The BLS approach can be described, very broadly, along the following lines. The approach builds on the insight that each worker possesses a unique set of skills that are matched in varying degrees to a firm's needs. Labor hours are differentiated to take account of some of the primary differences in skills among workers, in particular those skill differences that can be captured by differences in years of schooling and work experience. The methods developed to measure these skill differentials make use of the assumption, fundamental for productivity analysis, that factor inputs are paid the values of their marginal products. Within this framework, labor input is defined as a weighted average of the growth rates of groups of hours, and the groups of hours are defined by reference to specific levels of education and experience. Because labor input is inclusive of labor composition changes, the BLS measures of labor productivity and MFP can be related directly to these compositional changes.

One major task faced by the BLS researchers was to determine which worker characteristics reflect underlying skill differences. In developing the theory of human capital, Becker and Mincer (e.g., Becker 1975) examined the roles of education and on-the-job training in the acquisition of skills and earnings, with skills being the ultimate source of worker productivity. Education and training are the means of acquiring additional skills beyond innate abilities, and the economic incentives to invest in skills yield a direct relationship between earnings and education/training. However, data on training are rarely available in the form required by a macroeconomic productivity measurement effort, so on-the-job training is not a practical basis for differentiating workers. Mincer (1974) attacked this problem by developing a wage model that related training investments to the length of work experience.

The BLS methodology took advantage of Mincer's model by developing time series on work experience and relating these data to other human capital variables. The BLS study cross-classifies hours of work by education and work experience for each sex. The choice of work experience, instead of commonly used variables such as age or the number of

12. Among the many studies of this impact by these two sets of researchers were Jorgenson, Gollop, and Fraumeni (1987) and Denison (1985). 
years since leaving school, is dictated by the close relationship between work experience and the amount of time that a worker can learn through working.

The BLS approach to these issues was developed not only by the examination of human capital theory and its implications for productivity measurement, but also by a close study of previous productivity research related to the measurement of labor input. Dale Jorgenson, Frank Gollop, and Barbara Fraumeni (1987; hereafter JGF) disaggregated the labor input of all employed persons into cells, cross-classified by several characteristics of labor and by several dimensions of the structure of the economy. Further, Edward Denison (1985) provided data on the contribution to changes in output of each of several pertinent characteristics of labor. In both cases, information on the earnings of labor-fundamentally, information on the prices of the different types of labor - was used to provide weights for combining heterogenous labor inputs. ${ }^{13}$ This use of earnings data reflects the common assumption that earnings of different types of labor reflect their respective marginal value products. One unique aspect of the BLS study was to develop labor market prices for each characteristic rather than to use average earnings data for bundles of traits. ${ }^{14}$

The labor composition series was introduced in a BLS (1993) bulletin, prepared mainly by Larry Rosenblum. This followed earlier work by Kent Kunze [1979]; William Waldorf, Kunze, Rosenblum, and Michael Tannen (1986); Edwin Dean, Kunze, and Rosenblum (1988); and Rosenblum, Dean, Mary Jablonski, and Kunze (1990).

\subsubsection{The Construction of the BLS Labor Composition Series}

To implement the methodology just described, estimates of the prices of each relevant type of labor are obtained from annually fitted hourly earnings functions. BLS then accepts the coefficients for schooling and experience as good approximate measures of the contribution of the skills associated with schooling and experience to both earnings and worker productivity.

The wage model is specified as

$$
\ln \left(W_{i j k}\right)=a+b S_{i}+c X_{j}-d X_{j}^{2}+f Z_{k}
$$

The log of the wage, $W_{i j k}$, is a function of $i$ years of schooling, $S ; j$ years of experience, $X$; and the $k$ th bundle of other traits, $Z$. In line with the JGF approach and much of the human-capital literature, separate equations are estimated for men and women. In this equation, the parameters $b, c$, and

13. The BLS methodology includes the aggregation of different types of labor using Tornqvist indexes, consistent with the procedure introduced by Jorgenson and his colleagues. This aggregation approach is consistent with production theory and permits the incorporation of worker heterogeneity by modelling differences in workers' marginal products.

14. For a discussion of similarities and differences between the BLS approach and the approaches of JGF and Denison, see appendices F and A of BLS (1993). 
$d$ measure the roles of education and experience in determining wages for men and women. First- and second-order experience terms are included to capture the observed parabolic pattern of earnings with experience. Although the full equation is estimated, only the differences in earnings by education and experience are used directly to estimate changes in labor composition. However, the average effect over all other characteristics, $\bar{Z}$, is added to the intercept. ${ }^{15}$

To estimate the wage equations, hourly earnings are constructed from data available in the March supplement to the Current Population Survey (along with information from the decennial censuses for years before 1967). The education variable is defined for seven schooling groups, with zero through four years of schooling as the lowest schooling group and seventeen years or more as the highest.

Labor-force experience in this equation is not the commonly used "potential experience" - that is, age minus years of schooling minus 6 . Instead, actual quarters of work experience are estimated. The estimating equations make use of actual quarters of work experience reported to the Social Security Administration. ${ }^{16}$ Although the amount of work experience assigned to each type of worker does not change over time, shifts in the distribution of workers among categories do occur annually, allowing for changes in the average amount of work experience.

Table 2.3 shows estimated average annual growth rates of labor input, hours, and labor composition change for the private non-farm business sector. Growth rates for total labor input are produced by combining the changes in hours and labor composition.

Several results of this computation of labor input are noteworthy. First, because labor input rose more rapidly than did the direct aggregate of hours, there is a decrease in the estimated growth rate of MFP. Increases in skills, as measured by the labor composition shifts, led to faster labor input growth and slower MFP growth. ${ }^{17}$

15. For a full discussion of the estimating equation used, see appendices A and E of BLS (1993).

16. Estimated work experience is developed as a function of potential experience, a set of schooling dummy variables, the interaction of potential experience and schooling variables, other work experience variables, and selected demographic variables. For women, the estimating equations make use of number of children and marital status. The experience equation was estimated using detailed information for 1973 from an exact-match file linking Social Security data with Current Population Survey and Internal Revenue Service records. For each type of worker, the coefficients from the 1973 equation are used to estimate work experience. To implement the equation, it was necessary to construct annual matrices of hours worked by each age-experience-sex group. These matrices have 504 cells for men and 4,032 cells for women.

17. Note, however, that the contributions of labor composition change are smaller than the figures presented in table 2.3. The calculation of this contribution must take into account an estimate of the elasticity of output with respect to labor input; the best estimate of this elasticity is provided by labor's share of input, roughly two-thirds at the macro level. For further information on the contribution of labor composition change, see tables 2.4 and 2.5 and the accompanying text. 
Table 2.3

Labor Input, Hours, and Labor Composition Change in Private Nonfarm Business, Average Annual Growth Rates for Selected Time

Periods, 1948-98

\begin{tabular}{cccc}
\hline Year & $\begin{array}{c}\text { Labor } \\
\text { Input }\end{array}$ & $\begin{array}{c}\text { Hours of } \\
\text { All Persons }\end{array}$ & $\begin{array}{c}\text { Labor } \\
\text { Composition }\end{array}$ \\
\hline $1948-98$ & 1.8 & 1.5 & 0.3 \\
$1948-73$ & 1.5 & 1.2 & 0.2 \\
$1973-98$ & 2.1 & 1.7 & 0.4 \\
$1973-79$ & 2.0 & 1.9 & 0.0 \\
$1979-90$ & 2.1 & 1.6 & 0.5 \\
$1990-98$ & 2.3 & 1.7 & 0.6 \\
\hline
\end{tabular}

Note: Hours of all persons plus labor composition may not sum to labor input due to rounding.

A second noteworthy result is that between 1962 and 1979, the growth rate of labor composition declined to zero. This period coincided with both the entrance of the baby boom generation into the labor market and the rapidly rising labor participation rates for women. This decline contributed to the post-1973 slowdown in overall growth in output per hour.

A third important result is that the growth rate of labor composition change increased after 1979 and, for the first time, is about one-third as large as the growth in the direct aggregate of hours worked, in the private non-farm business sector.

A fourth result is not shown in table 2.3, but is presented in the bulletin that introduced these data. The researchers who undertook the labor composition study attempted to find a method for determining the contribution of the separate workforce traits-education, experience, and gender-to the overall trend in labor composition. The research concluded that exact measures of the separate traits would require a set of highly unlikely assumptions. Among other problems, an hour of work must be divisible into separate service flows for each trait. Consequently, no study of labor composition change is likely to produce an exact decomposition. ${ }^{18}$

Recently, Linda Moeller (1999) completed a study aimed at updating the experience equation using the Survey of Income and Program Participation (SIPP). BLS plans to integrate this work into its procedures for measuring labor composition.

18. See BLS (1993, Appendix H) and Rosenblum et al. (1990). Nonetheless, Rosenblum and his colleagues attempted to provide plausible estimates of the separate contributions of the various traits, by making heroic assumptions within the framework of the BLS labor composition model (BLS 1993, appendix H). Two of the results of this exercise can be described as follows. First, it appeared that the long-term increasing trend in labor composition was due predominantly to rising educational levels. Second, the turning points in labor composition trends between subperiods (such as the increased growth after 1979) were apparently due to changes in work experience. 


\subsubsection{Hours at Work}

The actual input of labor into the production process is more closely approximated by hours at work than by hours paid. Yet the Current Establishment Survey, the main source of the hours data used in the BLS productivity program, is collected as hours paid. The NAS panel $(1979,125)$ recognized that this situation was unsatisfactory.

The BLS's Hours at Work Survey ${ }^{19}$ has been used to convert the paid hours of nonagricultural production and nonsupervisory employees to an hours-at-work basis. This work is described by Jablonski, Kunze, and Otto (1990) and in BLS (1997). Hours at work exclude all forms of paid leave, but include paid time for travel between job sites, coffee breaks, and machine downtime. Hence, labor productivity in the BLS major sector work is essentially measured as the ratio of output to hours at work. Labor input in the MFP major sector series and the KLEMS manufacturing series (the acronym is explained in section 2.5.1) is also measured as hours at work.

\subsubsection{Fisher Indexes for Output in Major Sectors}

Earlier, this paper examined the introduction of superlative indexes into the BLS multifactor productivity measures in 1983. However, until February 1996, BLS used the BEA constant-dollar output data for its major sector productivity series.

In 1992, the BEA first introduced two new indexes of real GDP and its major components, both based on the Fisher index method, as alternatives to its constant-dollar indexes. One of these two new indexes was presented in annually chained form - the chain-type annual-weighted index. In 1996, BEA adopted the chain-type annual-weighted series as its featured measure for GDP and its major components, and BLS incorporated this type of output measure into its major sector labor-productivity series. ${ }^{20}$

\subsubsection{Trends in Major Sector Multifactor Productivity}

BLS updates the MFP study about once a year. The aim of this work is to examine some of the sources of economic growth. Table 2.4 shows the results through 1998. The trend in output per hour is attributable to growth in capital intensity (as in Solow's equation, which we discussed earlier), labor composition, and MFP. In addition, effects of expenditures

19. This survey of about 5,500 establishments has collected annual ratios of hours at work to hours paid since 1981. Ratios are developed for each two-digit SIC industry within manufacturing and for each one-digit industry outside manufacturing. Unpublished data and other survey information have been used to extend the annual ratios back to 1947 as well as to develop ratios for nonproduction and supervisory workers.

20. This means that all input indexes and most output indexes used in the BLS productivity measurement program are Törnqvist indexes, while some output indexes are Fisher indexes. This difference is not regarded as significant. For further discussion, see Dean, Harper, and Sherwood (1996); Dean, Harper, and Otto (1995); and Gullickson (1995). 
Table 2.4

Compound Average Annual Rates of Growth in Output per Hour of All Persons, the Contributions of Capital Intensity, Labor Composition, and MFP, by Major Sector, 1948-98 and Subperiods

\begin{tabular}{|c|c|c|c|c|c|}
\hline Item & $1948-98$ & $1948-73$ & 1973-79 & $1979-90$ & $1990-98^{\mathrm{a}}$ \\
\hline \multicolumn{6}{|l|}{ Private business ${ }^{b}$} \\
\hline Output per hour of all persons & 2.5 & 3.3 & 1.3 & 1.6 & 1.9 \\
\hline $\begin{array}{l}\text { Contribution of capital } \\
\text { intensity }\end{array}$ & 0.8 & 1.0 & 0.7 & 0.7 & 0.6 \\
\hline $\begin{array}{l}\text { Contribution of labor } \\
\text { composition }^{\mathrm{d}}\end{array}$ & 0.2 & 0.2 & 0.0 & 0.3 & 0.4 \\
\hline Multifactor productivity ${ }^{\mathrm{e}}$ & 1.4 & 2.1 & 0.6 & 0.5 & 0.9 \\
\hline \multicolumn{6}{|l|}{ Private nonfarm business ${ }^{\mathrm{b}}$} \\
\hline Output per hour of all persons & 2.2 & 2.9 & 1.2 & 1.4 & 1.8 \\
\hline $\begin{array}{l}\text { Contribution of capital } \\
\text { intensity }^{c}\end{array}$ & 0.8 & 0.9 & 0.7 & 0.8 & 0.6 \\
\hline $\begin{array}{l}\text { Contribution of labor } \\
\text { composition }^{\mathrm{d}}\end{array}$ & 0.2 & 0.2 & 0.0 & 0.3 & 0.4 \\
\hline Multifactor productivity ${ }^{\mathrm{e}}$ & 1.2 & 1.9 & 0.4 & 0.3 & 0.9 \\
\hline \multicolumn{6}{|l|}{ Contribution of $R \& D$ to } \\
\hline MFP & 0.2 & 0.2 & 0.1 & 0.2 & 0.2 \\
\hline
\end{tabular}

Note: The sum of MFP and the contributions may not equal labor productivity due to independent rounding.

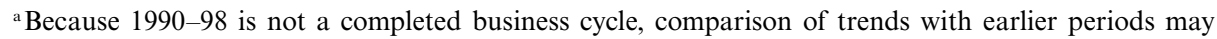
be misleading.

${ }^{\mathrm{b}}$ Excludes government enterprises.

${ }^{\mathrm{c}}$ Growth rate in capital services per hour $\times$ capital's share of current dollar costs.

${ }^{\mathrm{d}}$ Growth rate of labor composition (the growth rate of labor input less the growth rate of hours of all persons) $\times$ labor's share of current dollar costs.

${ }^{\mathrm{e}}$ Output per unit of combined labor and capital inputs.

on research and development are estimated using methods published by BLS (1989) based on work by Leo Sveikauskas (1986).

The post-1973 productivity slowdown is clearly evident in table 2.4 . A slowdown in capital intensity made a modest contribution to the labor productivity slowdown. While labor composition effects contributed 0.2 to the slowdown during the 1973-1979 period, these effects have actually boosted labor productivity since 1979 . The dominant source of the slowdown, however, is MFP. Since MFP is calculated as a residual and reflects many factors, the major factors underlying the slowdown are not evident in the BLS measurement model. The causes of the slowdown have been the subject of intensive investigation.

As we have seen, the BLS procedures involve a number of elements designed to ensure consistency of the measures with production theory. These involve aggregating labor, capital, and output from detailed data using value share weights and superlative index numbers. In table 2.5 we compare the BLS "production theory" measures (bold print) to alternatives based on more traditional measurement techniques. (Note that table 
2.5 is reproduced from Dean, Harper, and Sherwood 1996 and does not contain the latest BLS data. It is not feasible to update some of the results in this table.) Since 1979, production theory based MFP has grown very little. Although MFP itself is not a traditional measure, if it were put together from output, labor, and capital data that were measured using traditional techniques, we would find MFP growing 0.8 percent per year from 1979 through 1990 and 1.8 percent during the period 1990-1994.

\subsection{Industry Productivity Work}

BLS found guidance for its work on aggregate capital measurement and labor composition measurement in the economics literature. The literature provides additional guidance on industry productivity measurement and on the issue of comparing industry and aggregate productivity measures.

Table 2.5

Output and Inputs: Measures Based on Production Theory Compared to Traditional Measures

\begin{tabular}{|c|c|c|c|c|}
\hline & $1948-73$ & $1973-79$ & 1979-90 & $1990-94$ \\
\hline \multicolumn{5}{|l|}{ Output } \\
\hline Production theory & 4.1 & 2.9 & 2.6 & 2.1 \\
\hline Traditional (constant $87 \$$ ) & 3.8 & 2.4 & 2.7 & 2.9 \\
\hline Difference & 0.3 & 0.5 & -0.1 & -0.8 \\
\hline \multicolumn{5}{|l|}{ Less weighted labor input ${ }^{\mathrm{a}}$} \\
\hline Production theory & 1.0 & 1.4 & 1.5 & 1.2 \\
\hline Traditional & 0.8 & 1.4 & 1.1 & 0.6 \\
\hline Difference & 0.2 & 0.0 & 0.4 & 0.6 \\
\hline Effects of education & 0.2 & 0.3 & 0.3 & 0.4 \\
\hline Effects of experience & -0.1 & -0.3 & 0.1 & 0.2 \\
\hline Other effects & 0.0 & 0.0 & 0.0 & 0.0 \\
\hline \multicolumn{5}{|l|}{ Less weighted capital input ${ }^{\mathrm{a}}$} \\
\hline Production theory & 1.2 & 1.2 & 1.2 & 0.6 \\
\hline Traditional & 0.9 & 0.9 & 0.9 & 0.5 \\
\hline Difference & 0.3 & 0.3 & 0.3 & 0.1 \\
\hline \multicolumn{5}{|l|}{ Multifactor productivity } \\
\hline Production theory & 1.9 & 0.3 & 0.0 & 0.3 \\
\hline Traditional $^{\mathrm{b}}$ & 2.1 & 0.1 & 0.8 & 1.8 \\
\hline Difference & -0.2 & 0.2 & -0.8 & -1.5 \\
\hline
\end{tabular}

Source: Dean, Harper, and Sherwood 1996.

Notes: Estimation of MFP growth in the private nonfarm business sector. The "private nonfarm business" sector excludes government enterprises, while these enterprises are included in the "nonfarm business" sector. Note also that the sums presented in this table may not equal the totals due to rounding.

${ }^{\text {a }}$ For each pair of successive years, the growth rate of each input is multiplied by that input's average share in the value of output for the two years. The data reported are averages of this result over the time period.

${ }^{\text {b}}$ The MFP trend based on production theory minus the "difference" associated with output plus the sum of the two "differences" associated with labor and capital. 
This literature stresses the importance of taking account of the goods and services sold by one industry to another. These transactions are included in gross output measures. In computing MFP, these intermediate transactions should be reflected in input measures. Estimates of real value-added output treat the issue of intermediates in a restrictive way. The literature also stresses the importance of using nonrestrictive index number formulas at the industry level.

In this section we discuss the development of measures of MFP for the manufacturing sector and its two-digit level subsectors. We then describe recent improvements in the BLS program to measure labor productivity and MFP for more detailed industries.

\subsubsection{Expansion of Multifactor Productivity Measures for Manufacturing to Include Intermediate Inputs}

The NAS (1979) report recommended that BLS produce measures of intermediate inputs, as well as capital and labor inputs. Frank Gollop, in one section of the NAS report (Gollop 1979) and in a subsequent revised treatment of the same issues (Gollop 1981), discussed the role of intermediate inputs in the measurement of MFP. The correct treatment of MFP varies depending on whether the MFP measurement task is at a highly aggregate level or at the level of detailed industries. At a highly aggregate level, the analyst's interest may appropriately be focused on final product. This is because gross domestic product excludes intermediate inputs in order to avoid double counting. Aggregate production functions, including the work of Solow (1957) on productivity, described the entire economy and so included measures of final product.

For industry-level work, however, Gollop and others explained that it was a mistake to ignore intermediate inputs - those purchased from other industries. A different concept of output is also appropriate. Gross outputs, defined as total shipments adjusted for inventory change, should be compared to measures of labor, capital, and intermediate input. This approach was implemented by Berndt and Wood (1975) when they used Census of Manufactures data to estimate MFP for two-digit manufacturing industries.

As with capital measurement, the BLS work on manufacturing proceeded in several stages. In BLS (1983), measures of manufacturing MFP compared net outputs to labor and capital inputs. Data from the NIPA on real "gross product originating" (GPO) in manufacturing were used to measure net output. GPO data are net in the sense that intermediate inputs are subtracted from gross output. In concept, they are closely akin to value added.

At the same time, BLS was experimenting with a data set for total manufacturing that compared gross output to capital, labor, energy, and materials. Such data were used in research by Norsworthy and Harper (1981) and by Norsworthy and Malmquist (1983). 
When capital measurement at the two-digit industry level became feasible, BLS began work on an MFP series for two-digit manufacturing industries that included intermediate inputs. In building these measures, BLS made use of definitions proposed by Domar (1961). Domar had used production functions to develop a structure for relating industry and aggregate MFP measures. The key was to define the output of any industry or sector to include intermediate products it ships to other sectors while defining inputs to include intermediates purchased from other sectors. At the same time, intermediate transactions occurring between establishments within the industry or sector were to be excluded from both outputs and inputs. Gollop (1979) referred to measures conforming to these definitions as "sectoral" outputs and inputs and recommended that BLS use them. $^{21}$

A new BLS data set on MFP for manufacturing and two-digit manufacturing industries compared sectoral outputs to inputs of capital and labor as well as to three categories of intermediate inputs: energy, nonenergy materials, and purchased business services. More or less borrowing letters from each input, BLS refers to these as KLEMS measures. ${ }^{22}$ In a 1986 conference paper, Harper and Gullickson discussed the interpretation of trends in these input series for manufacturing and manufacturing industries, cautioning that changes in factor proportions were linked, in theory, to changes in relative factor prices. MFP measures from this data set were formally presented as new BLS measures in Gullickson and Harper (1987). More recently, BLS (1996) began publishing the new KLEMS MFP measures for total manufacturing in place of the initial comparisons of GPO to capital and labor inputs. In addition, the annual "sectoral output" series has replaced BEA's "gross product originating" as the basis for annual movements in output for the output per hour measures for manufacturing that BLS publishes each quarter. ${ }^{23}$ These changes in the quarterly series were described by Dean, Harper, and Otto (1995).

\subsubsection{Improvements in the Productivity Measurement Program for Detailed Industries}

For many years, BLS has developed, maintained, and published industry productivity measures at the three- and four-digit industry level. The

21. This approach had been used in many studies by Jorgenson and his associates, such as Jorgenson, Gollop, and Fraumeni (1987).

22. Sectoral output was based on four-digit level shipment data from the Census of Manufactures. Shipments were adjusted for inventory changes and for the exclusion of "intrasectoral" flows of intermediates, then deflated with price indexes. A Tornqvist index of five types of fuels was derived from data from the U.S. Department of Energy. The annual series on nonenergy materials and services were derived from data from the BLS Office of Employment Projections. These, in turn, were based on BEA's benchmark input-output tables. Deflation was accomplished with NIPA price indexes.

23. The Industrial Production Indexes of the Federal Reserve Board are still used to estimate quarterly movements in this series. 
literature cited previously in the discussion of improvements in the data series for major sector and two-digit manufacturing industry measures has also been examined for its implications for these detailed industry data. In particular, the work of Solow, Domar, Jorgenson, and Diewert suggests that particular methods are appropriate to the development of such measures. This work suggests (1) the use of the sectoral output concept in developing MFP series; (2) aggregation from detailed product information using superlative indexes, such as the Tornqvist index; and (3) development of major sector productivity measures by aggregation of industry input and output data.

\subsubsection{Implementation of the Improvements}

As of the mid-1970s, the BLS industry measurement program could be described along the following lines. Output indexes were calculated by a fixed weight formula, with the weights changed (in most cases) every five years. Production indexes for detailed types of output were produced by one of two methods. The indexes in most industries were computed from information on physical quantities produced. In other industries, time series on nominal output data for detailed types of goods or services were divided by corresponding price indexes. The price indexes reflected price changes relative to a specific year, the base year. The detailed output indexes computed by one of these two procedures were then weighted, using base-year weights, and added to produce an aggregate index of output of the industry. With each new economic census-generally, every five years - new weights were introduced and the resulting series were linked. The types of weights used varied: for some series, unit value weights-or, roughly, price weights - were used; for other series, employment weights or other weights were used. The resulting output indexes were then divided by indexes of hours, generally developed from establishment surveys. For details on this measurement methodology, see Dean and Kunze (1992).

As of 1975, only fifty-three measures were prepared and published annually. The program was producing only labor productivity, or output per hour, measures. No MFP series were produced.

The improvements in the BLS productivity measurement program for detailed industries can be best explained by describing four separate activities that were undertaken between the mid-1970s and the year 2000.

First, a rapid expansion of BLS's original industry productivity measures was undertaken. While the number of annually published industry productivity measures in 1975 was fifty-three, by 1985, the BLS was publishing 140 measures. In addition, the number of measures based on deflated nominal data was expanded greatly and the measures based on physical quantity data became a small proportion of the total.

Second, development by BLS of MFP measures at the three-digit industry level began with measures for steel (Standard Industrial Classification 
[SIC] 331) and automobiles (SIC 371) constructed by Sherwood and his BLS colleagues (as explained by Sherwood, 1987). As of 2000, data for ten industries are regularly published. ${ }^{24}$ As noted earlier, MFP measures are prepared for total manufacturing and for 20 two-digit manufacturing industries. Both the three-digit and the two-digit manufacturing series are prepared using sectoral output and inputs of capital, labor, and intermediate purchased inputs. Tornqvist indexes are used to aggregate inputs as well as outputs.

Third, in 1995, most of the output measures for the labor productivity series were converted from fixed weight indexes, with the weights periodically updated, to Tornqvist indexes. Relative revenue weights were used to aggregate detailed product indexes in place of employment weights. At the same time, most of the output indexes were converted from gross output to sectoral output measures. This work was described by Kunze, Jablonski, and Klarqvist (1995).

The fourth stage of improvement of the industry productivity measures has yielded a very substantial increase in the number of labor productivity measures for detailed industries in manufacturing, as well as for serviceproducing and other nonmanufacturing industries. Output, hours, and output per hour series were developed for all three- and four-digit industries in manufacturing and in retail trade. Coverage was expanded substantially, mostly at the four-digit level, in transportation, communications, utilities, and mining industries. By 2000, BLS was publishing labor productivity measures for about 500 industries. In addition, BLS introduced hourly compensation and unit labor cost series for detailed industries. By 2000, BLS was publishing these series for 173 industries, mostly at the three-digit level.

This new expanded industry data set will prove useful in developing new insights into productivity trends in service-producing and other industries and in the ongoing effort to improve output and productivity series for service-producing industries.

\subsection{Summary and Conclusions}

For the past twenty years, the main thrust of the BLS productivity program has been to develop measures of multifactor productivity. These measures have been presented in a context of explaining the sources of growth in output per hour. Therefore, the BLS approach resembles that of Ed Denison, who sought to attribute output growth to specific sources. However, BLS has rationalized its work, using the Solow equation and using measurement techniques developed by Jorgenson and others. It would 
be accurate to say that BLS has focused on explanations that meet the following criteria: (1) They can be based on index number formulations. (2) They can be firmly based on simple assumptions about how firms would operate in equilibrium. (3) They can be supported with adequate data from the marketplace.

By basing the explanations on a particular body of theory, BLS does impose a number of assumptions that affect the conclusions. However, a theory-based approach has an important advantage over a more ad hoc approach: The assumptions are made explicitly and it is therefore clear what is being assumed. Another advantage is that a theory-based approach is often useful in consistently guiding the many choices that must be made in preparing data on output, prices, and productivity.

Nevertheless, the criteria have ruled out inclusion of many sorts of explanations of productivity. As a result, BLS publications include shorter lists of explanatory factors than did the many books written by Denison. The BLS publications also have cautioned readers that productivity trends reflect "the joint influences on economic growth of technological change, efficiency improvements, returns to scale, reallocation of resources due to shifts in factor inputs across industries, and other factors" (see, for example, BLS 2000).

Most of the papers presented at this conference have explored alternatives or supplements to the BLS approach. These include econometric specifications (in addition to the index number approach), the use of vintage capital models (rather than the Solow residual approach), departure from the equilibrium assumptions, the use of firm-specific data (instead of aggregate data), and the introduction of environmental variables.

These approaches might yield additional information about the sources of productivity change. Each of these approaches departs, in one or more ways, from the traditional BLS criteria. It appears such departures are essential to gain insight into various issues. For example, econometric methods can be used to estimate more complicated specifications of production than index number methods can. This can allow a more realistic description of behavior and the investigation of a longer list of explanations of productivity change. As another example, analysis of data on individual firms can lead to explanations of productivity change that do not emerge from aggregate data, such as effects of the entry of new firms.

BLS already has done some research along the lines of some of these alternative approaches. It appears to us that it may be valuable to pursue some of these directions further. Ideally, data would emerge from this work that could be tied in to the Solow framework. More likely than not, this will prove difficult. We may need to present such work in supplementary articles and tables. Pursuit, by BLS, of any of the alternative approaches will have other drawbacks. Some are resource intensive, some are narrow in scope, and some involve tenuous assumptions or limited data. This type 
of work will be valuable, nonetheless, if it allows attention to be focused on additional sources of productivity. BLS intends to pursue at least some of these alternative approaches.

Recently, a major distraction from exploring new explanations of productivity change has been questions about the output measures themselves. There have been growing concerns that the government may be underestimating productivity, particularly in service industries. BLS has recognized the importance of this issue, and recently three articles (by Dean 1999, Eldridge 1999, and Gullickson and Harper 1999) investigating this issue appeared in the Monthly Labor Review. It could not be conclusively demonstrated that productivity trends have been understated. Nevertheless, evidence was found to indicate that output and productivity trends were understated in several industries, including banking and construction.

In the meantime, we expect to pursue some of the suggested additional approaches to analyzing productivity. However, we also expect that the aggregate MFP measures will continue to constitute one of our most important products. For policy purposes, it is important to have data on the general characteristics of the economy.

\section{References}

Ball, V. Eldon, and Michael J. Harper. 1990. Neoclassical capital measures using vintage data: An application to breeding livestock. Washington, D.C.: Bureau of Labor Statistics.

Becker, Gary. 1975. Human capital. New York: Columbia University Press.

Berndt, Ernst R., and Jack E. Triplett, eds. 1990. Fifty years of economic measurement. Chicago: University of Chicago Press.

Berndt, Ernst R., and David O. Wood. 1975. Technology, prices, and the derived demand for energy. Review of Economics and Statistics 57 (3): 259-68.

. 1984. Energy price changes and the induced revaluation of durable capital in U.S. manufacturing during the OPEC Decade. MIT Energy Lab Report no. 84-003. Cambridge: MIT.

Bureau of Labor Statistics. 1959. Trends in output per man-hour in the private economy, 1909-1958. Bulletin 1249. GPO.

1983. Trends in multifactor productivity, 1948-81. Bulletin 2178. GPO.

1989. The impact of research and development on productivity growth. Bulletin 2331.

. 1993. Labor composition and U.S. productivity growth, 1948-90. Bulletin 2426. GPO.

- 1996. Multifactor productivity trends, 1994. News Release no. 95-518. Washington, D.C.: U.S. Department of Labor.

. 1997. BLS handbook of methods. Bulletin 2490. GPO.

1998. Revisions to capital inputs for the BLS multifactor productivity measures. March 6. Washington, D.C.: Bureau of Labor Statistics, Office of Productivity \& Technology. 
2000. Multifactor productivity trends, 1998. News Release no. 00-267, 21 September. Washington, D.C.: U.S. Department of Labor.

Christensen, Laurits R., and Dale W. Jorgenson. 1969. The measurement of U.S. real capital input, 1929-1967. Review of Income and Wealth ser. 15, no. 4 (December): 293-320.

Dean, Edwin R. 1999. The accuracy of the BLS productivity measures. Monthly Labor Review 122 (2): 24-34.

Dean, Edwin R., Michael J. Harper, and Phyllis F. Otto. 1995. Improvements to the quarterly productivity measures. Monthly Labor Review 118 (10): 27-32.

Dean, Edwin R., Michael J. Harper, and Mark K. Sherwood. 1996. Productivity measurement with changing weight indices of output and inputs. In Industry productivity: International comparison and measurement issues, 183-215. Paris: Organization for Economic Cooperation and Development.

Dean, Edwin R., and Kent Kunze. 1992. Productivity measurement in service industries. In Output Measurement in the Service Sectors, ed. Zvi Griliches, 73-101. Chicago: University of Chicago Press.

Dean, Edwin R., Kent Kunze, and Larry S. Rosenblum. 1988. Productivity change and the measurement of heterogeneous labor inputs. Paper presented at Conference on New Measurement Procedures for U.S. Agricultural Productivity. 31 March-1 April. Available from Bureau of Labor Statistics, Washington, D.C.

Denison, Edward F. 1974. Accounting for U.S. economic growth, 1929-1969. Washington, D.C.: Brookings Institution.

- 1985. Trends in American economic growth, 1929-1982. Washington, D.C.: Brookings Institution.

Diewert, W. Erwin. 1976. Exact and superlative index numbers. Journal of Econometrics 4 (4): 115-45.

-1980. Aggregation problems in the measurement of capital. In The measurement of capital, ed. Dan Usher, 433-528. Chicago: University of Chicago Press.

Domar, Evsey D. 1961. On the measurement of technical change. Economic Journal 71 (284): 709-29.

Dulberger, Ellen R. 1989. The application of a hedonic model to a quality-adjusted price index for computer processors. In Technology and capital formation, ed. D. W. Jorgenson and R. Landau, 37-75. Cambridge: MIT Press.

Eldridge, Lucy P. 1999. How price indexes affect BLS productivity measures. Monthly Labor Review 122 (2): 35-46.

Fraumeni, Barbara M. 1997. The measurement of depreciation in the U.S. national income and product accounts. Survey of Current Business 77 (7): 7-23.

Goldberg, Joseph P., and William T. Moye. 1984. The first hundred years of the Bureau of Labor Statistics. Bulletin 2235. GPO.

Gollop, F. M. 1979. Accounting for intermediate input: The link between sectoral and aggregate measures of productivity. In Measurement and interpretation of productivity, 318-33. Washington, D.C.: National Academy of Sciences.

-1981. Growth accounting in an open economy. Boston College Department of Economics, Working Paper, March.

Gorman, John A., John C. Musgrave, Gerald Silverstein, and Kathy A. Comins. 1985. Fixed private capital in the United States. Survey of Current Business 65 (7): 36-59.

Gullickson, William. 1995. Measurement of productivity growth in U.S. manufacturing. Monthly Labor Review 118 (7): 13-28.

Gullickson, W., and Michael J. Harper. 1987. Multifactor productivity in U.S. manufacturing, 1949-83. Monthly Labor Review 110 (10): 18-28. 
1999. Possible measurement bias in aggregate productivity growth. Monthly Labor Review 122 (2): 47-67.

Hall, Robert E. 1968. Technical change and capital from the point of view of the dual. Review of Economic Studies 35 (1): 35-46.

Hall, Robert E., and Dale W. Jorgenson. 1967. Tax policy and investment behavior. American Economic Review 57 (3): 391-414.

Harper, Michael J. 1983. The measurement of productive capital stock, capital wealth, and capital services. Bureau of Labor Statistics Working Paper no. 128. Washington, D.C.: BLS.

Harper, Michael J., Ernst R. Berndt, and David O. Wood. 1989. Rates of return and capital aggregation using alternative rental prices. In Technology and capital formation, ed. D. W. Jorgenson and R. Landau, 331-72. Cambridge: MIT Press.

Harper, Michael J., and William Gullickson. 1986. Cost function models and accounting for growth. Paper presented at annual meeting of the American Economic Association. 28-30 December, New Orleans, La. Available from the Bureau of Labor Statistics, Washington, D.C.

Hulten, Charles R., James W. Robertson, and Frank C. Wykoff. 1989. Energy, obsolescence, and the productivity slowdown. In Technology and capital formation, ed. D. W. Jorgenson and R. Landau, 225-58. Cambridge: MIT Press.

Hulten, Charles R., and Frank C. Wykoff. 1981. The estimation of economic depreciation using vintage asset prices: An application of the Box-Cox power transformation. Journal of Econometrics 15:367-96.

Jablonski, Mary, Kent Kunze, and Phyllis F. Otto. 1990. Hours at work: A new base for BLS productivity statistics. Monthly Labor Review 113 (2): 17-24.

Jorgenson, Dale W., Frank M. Gollop, and Barbara M. Fraumeni. 1987. Productivity and U.S. economic growth. Cambridge: Harvard University Press.

Jorgenson, Dale W., and Zvi Griliches. 1967. The explanation of productivity change. Review of Economic Studies 34 (99): 249-83.

Katz, Arnold, and Shelby Herman. 1997. Improved estimates of fixed reproducible tangible wealth, 1929-95. Survey of Current Business 77 (5): 69-92.

Kendrick, John W. 1976. The formation and stocks of total capital. New York: Columbia University Press.

Kunze, Kent. 1979. Evaluation of work force composition adjustment. Measurement and Interpretation of Productivity: 334-62. Washington, D.C.: National Academy of Sciences.

Kunze, Kent, Mary Jablonski, and Virginia Klarqvist. 1995. BLS modernizes industry labor productivity program. Monthly Labor Review 118 (7): 3-12.

Mark, Jerome A., and William Waldorf. 1983. Multifactor productivity: A new BLS measure. Monthly Labor Review 106 (12): 3-13.

Mincer, Jacob. 1974. Schooling, experience and earnings. New York: Columbia University Press.

Moeller, Linda. 1999. A second decade of slower U.S. productivity growth: Prototype labor composition indexes based on the SIPP. Washington, D.C.: BLS Office of Productivity and Technology.

National Academy of Sciences. 1979. Measurement and interpretation of productivity. Washington, D.C.: National Academy of Sciences.

Norsworthy, J. Randolph, and Michael J. Harper. 1981. The role of capital formation in the recent slowdown in productivity growth. In Aggregate and industrylevel productivity analyses, ed. Ali Dogramaci and Nabil R. Adam, 122-48. Boston: Martinus Nijhoff.

Norsworthy, J. Randolph, Michael J. Harper, and Kent Kunze. 1979. The slow- 
down in productivity growth: Analysis of some contributing factors. Brookings Papers on Economic Activity, issue no. 3:387-421.

Norsworthy, J. Randolph, and David Malmquist. 1983. Input measurement and productivity growth in Japanese and U.S. manufacturing. American Economic Review 73 (5): 947-67.

Oliner, Stephen D. 1993. Constant-quality price change, depreciation, and retirement of mainframe computers. In Price measurements and their uses, ed. M. F. Foss, M. E. Manser, and A. H. Young, 19-61. Chicago: University of Chicago Press.

Rosenblum, Larry, Edwin Dean, Mary Jablonski, and Kent Kunze. 1990. Measuring components of labor composition change. Paper presented at annual meeting of the American Economic Association. 28-30 December, Washington, D.C. Available from BLS.

Samuelson, Paul A. 1947. Foundations of economic analysis. Cambridge: Harvard University Press.

Sherwood, Mark K. 1987. Performance of multifactor productivity in the steel and motor vehicle industries. Monthly Labor Review (August): 22-31.

Solow, Robert M. 1957. Technical change and the aggregate production function. Review of Economics and Statistics 39 (3): 312-20.

Sveikauskas, Leo. 1986. The contribution of R\&D to productivity growth. Monthly Labor Review 109 (3): 16-20.

Tornqvist, Leo. 1936. The Bank of Finland's consumption price index. Bank of Finland Monthly Bulletin 10:1-8.

Triplett, Jack E. 1992. Measuring the capital stock: A review of concepts and data needs. Paper presented at Workshop on Measurement of Depreciation and Capital Stock, of the Conference on Research in Income and Wealth. 5 June, Washington, D.C. Available from BLS.

Waldorf, William, Kent Kunze, Larry Rosenblum, and Michael Tannen. 1986. New measures of the contribution of education and experience to U.S. productivity growth. Paper presented at American Economic Association Meeting. 28-30 December, New Orleans, La. Available from BLS.

Young, Allan H., and John C. Musgrave. 1980. Estimation of capital stock in the United States. In The measurement of capital, ed. Dan Usher, 23-68. Chicago: University of Chicago Press. 